\title{
An Intramuscular Multivalent Vaccine Against Pathogenic Escherichia Coli Injected in Suckling Piglets Reduced the Prevalence of Pathogenic E. Coli and Lawsonia Intracellularis Until Slaughter
}

\author{
Lívia Mendonça Pascoal \\ Universidade Federal de Goiás \\ Sarah Rodrigues Chagas ( $\sim$ sarahchagas94@gmail.com ) \\ Universidade Federal de Goiás \\ Francisco J. Pallarés \\ University of Murcia \\ Juan J. Quereda \\ CEU Cardinal Herrera University \\ Juan Manuel Herrero Medrano \\ Pig Improvement Company (PIC) \\ Antonio Muñoz \\ University of Murcia \\ Manuel Guillermo Ramis-Vidal \\ University of Murcia
}

\section{Research Article}

Keywords: colibacillosis, immunization, porcine enteric disease complex, real-time PCR, swine, virulence factors

Posted Date: December 14th, 2021

DOI: https://doi.org/10.21203/rs.3.rs-1129211/v1

License: @ (1) This work is licensed under a Creative Commons Attribution 4.0 International License. Read Full License 


\section{Abstract}

Background: The present study aims to evaluate the efficacy of an intramuscular multivalent Escherichia coli vaccine for suckling piglets against infection not only by pathogenic E. coli but also by pathogens involved in Porcine Enteric Disease Complex (PEDC). Vaccinated Group had piglets vaccinated at days 10 and 20 of life with Colidex-C® (Vetia Animal Health, Spain), and Control Group had piglets that received sterile saline solution injection at the same days of life. We collected fecal samples in the farm from animals presenting diarrhea and intestinal mucosa swabs and ileum and colon tissue at slaughter and then performed PCR to identify E. coli virulence factors genes. Furthermore, we performed PCR to identify Lawsonia intracellularis, Brachyspira hyodisenteriae, and Salmonella spp.

Results: Regarding fecal samples, $0 \%$ from Vaccinated Group was positive for E. coli, while Control Group had $94.1 \%$ of positive samples $(p<0.0001)$. With respect to intestinal mucosa swab, $0 \%$ of the samples from Vaccinated Group were positive for $E$. coli, while $100 \%$ from Control Group were positive $(p=0.001)$. Regarding ileum and colon tissue samples, $35 \%$ were positive for $E$. coli in Vaccinated Group and $85 \%$ in Control Group ( $p=0.001)$; Gcnt had a higher frequency of F41 ( $p=0.018), L T(p=0.018)$ and Sta ( $p=0.028)$ virulence factors genes. No sample was positive for Salmonella spp. nor for $B$. hyodisenteriae, but there were positive samples $L$. intracellularis; real-time PCR was performed and the frequencies found were $40 \%$ and $20 \%$ of ileum and colon positive samples in Vaccinated Group and 100\% for ileum and $70 \%$ for colon in Control Group ( $<<0.001$ for ileum and $p=0.001$ for colon).

Conclusion: The results indicate that the $E$. coli vaccine for piglets may be a strategy to control $E$. coli infection. E. coli vaccines emerge as a probable strategy to help control L. intracellularis and, maybe, other enteric pathogens of pigs not evaluated in this study.

\section{Introduction}

Escherichia coli-related diseases have always been a challenge for the swine industry, exacerbated by the intensification of pig production in the last decades. The importance of this disease is not limited to the productive and economic losses that it causes by itself, since the adhesion and production of toxins by pathogenic strains of $E$. coli may break the intestinal microbiome homeostasis and create favorable conditions for other enteric pathogens involved in Porcine Enteric Disease Complex (PEDC) such as Brachyspira sp., Salmonella sp., and Lawsonia intracellularis [1,2].

The classical clinical signs of colibacillosis may appear in piglets from suckling up to the nursery phase [3]. However, the pathochrony of collibacilary diarrhea has changed and can occur on animals even up to the finishing phase [4]. Apparently, this change was the result of different factors such as more intensive prophylaxis during nursery, stress during transportation at the beginning of finishing phase, stress due to batch mixing, feed changes, and water quality [4].

The usual prevention method includes (1) sows and gilts immunization to reduce the infectious pressure in farrowing crates and to confer maternal immunity to piglets, (2) and the pharmaceutical prevention by antimicrobials and zinc oxide in feed during nursery. Sow vaccination is an effective measure to prevent suckling piglets from pathogenic $E$. coli infection, but not to protect nursery, growing and finishing pigs since the maternal antibodies decrease just after weaning [5]. Furthermore, there is a worldwide tendency to reduce the use of antimicrobials on livestock animals, due to the development of multidrug-resistant bacteria and the risk they pose to human health [6,7]. This can lead to the worsening of diseases caused by E. coli and other pathogens.

The development of new measures to control E. coli on pig farms is necessary. One alternative approach is the vaccination of piglets, which may results in adaptive immunity that lasts over the pig's lifetime. Thus, the present study aims to evaluate the efficacy of an intramuscular multivalent $E$. coli vaccine for piglets against infection not only by pathogenic $E$. coli but also by $B$. hyodisenteriae, Salmonella sp., and L. intracellularis until slaughter.

\section{Materials And Methods}

\subsection{Animals and farm}

A total of 3,732 Duroc $x$ (Landrace $x$ Large White) were used. These animals came from Colidex- $\mathrm{C}^{\circledR}$ (Vetia Animal Health, Spain) sows that were vaccinated in the two previous pregnancies $\left(2 \mathrm{~mL}\right.$, intramuscular injection at $80^{\text {th }}$ day of gestation; injection in the neck, just behind the ear, using disposable needle $18 \mathrm{G} \times 1-1 / 2$ "). Piglets were divided into two experimental groups: Vaccinated Group, with 1,893 animals, vaccinated and revaccinated at days 10 and 20 of life with Colidex- $C^{\circledR}(0.5$ and $1 \mathrm{~mL}$, intramuscular injection in the neck, 
behind the ear; disposable needle $24 \mathrm{G} \times 3 / 4$ "); and Control Group, with 1,869 animals, injected with sterile saline solution at days 10 and 20 of life $(0.5$ and $1 \mathrm{~mL}$, intramuscular injection in the neck, behind the ear; disposable needle $24 \mathrm{G} \times 3 / 4 ")$. The animals were randomly assigned to each group.

Piglets were castrated in the first week of life (according to the Directive 2008/120/EC) and kept during the trial period without routine medication against enteric pathogens. The study was conducted in a three-sites-production system farm, with breeders, nursery, and finishers in the same geographical area (Province of Toledo, Spain). In the nursery phase, the animals were raised in three barns of 1,000 animals each, subdivided into three modules each. The size of the stalls was 2.7 square meters, which housed 12 piglets each. In the growing and finishing phases, there were 11 barns of 600 animals each, with a free surface area of 8.4 square meters where 12 animals were housed. Animals from the Vaccinated Group and Control Group were housed in the same barn but in different stalls. The stalls had identical size and environmental conditions (stall size, environmental temperature, number of drinkers, and feeders). The animals received feed (meal during nursery and pelleted during finishing), and water ad libitum. The facilities were managed under an all-in all-out system. Once they reached market weight (an average $107.82 \mathrm{Kg}$ body weight), pigs were sent to the slaughterhouse.

\subsection{Vaccine}

The vaccine used was Colidex- $C^{\circledR}$ (Vetia Animal Health, Spain), which is composed of a suspension of seven strains of $E$. coli, inactivated with formalin and heat, ensuring the presence of fimbriae antigens F4, F5, F41, F18, and F6; and of toxoids of heat-labile toxin (LT), heat-stable toxin (STa), verotoxin (VT) and hemolysin (Hly), combined with a toxoid of Clostridium perfringens Type C (Table 1). Each $2 \mathrm{ml}$ dose contained $2 \times 10^{9}$ micro-organisms from each of the bacterial strains inactivated with heat, $1.5 \times 10^{9}$ and microorganisms of each strain inactivated with formol and $300 \mathrm{Ul}$ of $\beta$ (beta) toxoid of $C$. perfringens. Vaccine lot number used in this study: 192761.

By the time the study was conducted, Vetia Animal Health was named Farco Veterinaria S.A. When the company changed its name, some changes were also made to the composition of the vaccine Colidex-C®. Because of that, the company's current website shows a different composition from the one shown in the present study.

Table 1 - Composition of the vaccine $(2 \mathrm{ml})$

\begin{tabular}{|ll|}
\hline Components of the vaccine & Concentration \\
\hline Escherichia coli inactivated (fimbriae F4ac), strain p6 & $\geq 1 \mathrm{RP}$ \\
\hline Escherichia coli inactivated (fimbriae F5), strain p1 & $\geq 1 \mathrm{RP}$ \\
\hline Escherichia coli inactivated (adhesins F5 + F41), strain p10 & $\geq 1 \mathrm{RP}$ \\
\hline Escherichia coli inactivated (adhesin F6), strain p2 and p4 & $\geq 1 \mathrm{RP}$ \\
\hline Escherichia coli inactivated (adhesin F18ab), strain p5 & $\geq 1 \mathrm{RP}$ \\
\hline Escherichia coli inactivated (adhesin F18ac), strain p9 & $\geq 1 \mathrm{RP}$ \\
\hline Escherichia coli, toxoid of heat-labile toxin & $\geq 10 \mathrm{Ul}$ \\
\hline Escherichia coli, toxoid of heat-stable toxin & $\geq 10 \mathrm{UI}$ \\
\hline Escherichia coli, toxoid of verotoxin & $\geq 10 \mathrm{UI}$ \\
\hline Escherichia coli, toxoid of hemolysin & $\geq 10 \mathrm{Ul}$ \\
\hline Clostridium perfringens type C, toxoid beta & $\geq 10 \mathrm{Ul}$ \\
\hline Mineral Oil (Marcol 52) & $0.76 \mathrm{ml}$ \\
\hline Montane 80 & $0.042 \mathrm{ml}$ \\
\hline Montanide 103 & $0.042 \mathrm{ml}$ \\
\hline
\end{tabular}

RP: Relative Potency of the antigen, according to a reference vaccine (Ph. Eur. m 0962)

UI: International Unit 


\subsection{Sampling}

\subsubsection{Feces of animals with diarrhea on the farm}

Fecal samples were collected from animals with diarrhea, individually or during a collective outbreak. If there was an outbreak at least 12 samples were taken. Samples were taken by swabs with Cary Blair agar gel transport medium (COPAN Diagnostics, Inc. Italy) and kept cold during transportation to the Reference Laboratory specialized in Escherichia coli (LREC) of the Faculty of Veterinary Medicine, University of Santiago de Compostela, Spain.

\subsubsection{Intestinal mucosa swabs at slaughter}

At slaughter, intestinal jejunum mucosa from five animals from each group was randomly sampled using a swab with Cary Blair agar gel transport medium (COPAN Diagnostics, Inc. Italy) and kept cold during transportation to LREC.

\subsubsection{Ileum and colon tissue at slaughter}

Fresh samples of ileum and colon were randomly taken at slaughter from 20 animals from each group. They were refrigerated and sent to the Cytogenetics and Genomics Laboratory of the Faculty of Veterinary of the University of Murcia, Spain.

\subsection{Samples analysis}

\subsubsection{Isolation and virulence factor genes of $E$. coli}

The tests performed in the LREC with diarrhea samples and intestinal mucosa swabs are described as follows. Bacterial colonies were grown on lactose-MacConkey agar plates at $37^{\circ} \mathrm{C}$ for $24 \mathrm{~h}$. An aliquot of confluent growth was inoculated into $30 \mathrm{ml}$ of Luria-Bertani broth, incubated with shaking at $37^{\circ} \mathrm{C}$ for $4 \mathrm{~h}$ and processed for DNA extraction as described previously [8,9]. Virulence factor genes were detected by conventional PCR (Blanco et al., 2004). Researchers investigated the presence of intimin (eae gene), fimbriae (F4, F5, F6, F18, and F41 genes), hemolysin (Hly), heat-labile toxin (LT), heat-stable enterotoxins (Sta and STb), and verotoxin (VT1 and VT2). Primer sequences are described in Table 2. Amplification products were analyzed by gel electrophoresis (1.5\% agarose) and UV transillumination $(300 \mathrm{~nm})$.

Table 2 - Characteristics of oligonucleotide sequences used for conventional PCR assays to detect E. coli virulence factor genes. 


\begin{tabular}{|c|c|c|c|c|}
\hline PCR and samples & $\begin{array}{l}\text { Virulence } \\
\text { factor }\end{array}$ & Oligonucleotide sequence (5'-3') & $\begin{array}{l}\text { Size of amplified product } \\
\text { (bp) }\end{array}$ & Reference \\
\hline \multirow[t]{24}{*}{$\begin{array}{l}\text { Conventional PCR, diarrhea and } \\
\text { swabs }\end{array}$} & \multirow[t]{2}{*}{ eae } & $\begin{array}{l}\text { F: GGA ACG GCA GAG GTT AAT } \\
\text { CTG CAG }\end{array}$ & \multirow[t]{2}{*}{775} & \multirow[t]{2}{*}{ [10] } \\
\hline & & R: GGC GCT CAT CAT AGT CTT TC & & \\
\hline & \multirow[t]{2}{*}{ Hly } & F: GGTGCAGCAGAAAAAGTTGTAG & \multirow[t]{2}{*}{1551} & \multirow[t]{2}{*}{ [11] } \\
\hline & & R: TCTCGCCTGATAGTGTTTGGTA & & \\
\hline & \multirow[t]{2}{*}{ LT } & F: GGCGACAGATTATACCGTGC & \multirow[t]{2}{*}{708} & \multirow[t]{2}{*}{ [12] } \\
\hline & & R: CCGAATTCTGTTATATATGTC & & \\
\hline & \multirow[t]{2}{*}{ STa } & F: ATTTTTATTTCTGTATTGTCTTT & \multirow[t]{2}{*}{176} & \multirow[t]{2}{*}{ [13] } \\
\hline & & $\begin{array}{l}\text { R: } \\
\text { GGATTACAACACAGTTCACAGCAGT }\end{array}$ & & \\
\hline & \multirow[t]{2}{*}{$\mathrm{STb}$} & F: ATCGCATTTCTTCTTGCATC & \multirow[t]{2}{*}{175} & \multirow[t]{2}{*}{ [12] } \\
\hline & & R: GGGCGCCAAAGCATGCTCC & & \\
\hline & \multirow[t]{2}{*}{ VT1 } & F: CGCTGAATGTCATTCGCTCTGC & \multirow[t]{2}{*}{302} & \multirow[t]{2}{*}{ [14] } \\
\hline & & R: CGTGGTATAGCTACTGTCACC & & \\
\hline & \multirow[t]{2}{*}{ VT2 } & F: CTTCGGTATCCTATTCCCGG & \multirow[t]{2}{*}{516} & \multirow[t]{2}{*}{ [14] } \\
\hline & & R: CTGCTGTGACAGTGACAAAACGC & & \\
\hline & \multirow[t]{2}{*}{ F4 } & F: GGTGATTTCAATGGTTCGGTC & \multirow[t]{2}{*}{773} & \multirow[t]{2}{*}{ [15] } \\
\hline & & R: ATTGCTACGTTCAGCGGAGCGC & & \\
\hline & \multirow[t]{2}{*}{ F5 } & $\begin{array}{l}\text { F: } \\
\text { CCAGCGCCCGGCAGTAATGACTGC }\end{array}$ & \multirow[t]{2}{*}{278} & \multirow[t]{2}{*}{ [16] } \\
\hline & & R: CCACCATTAGACGGAGCGCGG & & \\
\hline & \multirow[t]{2}{*}{ F6 } & $\begin{array}{l}\text { F: } \\
\text { GCGCCCGCTGAAAACAACACCAGC }\end{array}$ & \multirow[t]{2}{*}{467} & \multirow[t]{2}{*}{ [16] } \\
\hline & & R: GTACCGGCCGTAACTCCACCG & & \\
\hline & \multirow[t]{2}{*}{ F18 } & F: GGTACTGTTGCACCAAGCGG & \multirow[t]{2}{*}{225} & \multirow[t]{2}{*}{ [16] } \\
\hline & & R: CGACGCCTTAACCTCCTGCCCC & & \\
\hline & $\mathrm{F} 41$ & F: GGCTATGGAAGACTGGAGAGGG & 551 & [16] \\
\hline & & R: GGGGTGACTGAGGTCATCCC & & \\
\hline
\end{tabular}

The Cytogenetics and Genomics Laboratory of the Faculty of Veterinary of the University of Murcia used the ileum and colon tissue samples for the detection of the virulence factor genes F4, F5, F41, F18, F6, LT, and STa by real-time PCR-based "Plus/Minus" assay (methods described on the Additional file). Primer sequences are described in Table 3. A commercial DNA extraction kit (DanaPure Spin Kit. Genedan S.L., Spain) was used to extract DNA from the ileum and colon according to the manufacturer's recommendation.

Table 3 - Characteristics of oligonucleotide sequences used for real-time PCR-based "Plus/Minus" assay to detect E. coli virulence factor genes. 
PCR and samples

\begin{tabular}{|c|c|c|c|}
\hline $\begin{array}{l}\text { Virulence } \\
\text { factor }\end{array}$ & Oligonucleotide sequence (5'-3') & $\begin{array}{l}\text { Size of } \\
\text { amplified } \\
\text { product (bp) }\end{array}$ & Reference \\
\hline \multirow[t]{2}{*}{ F4 } & F: GGTTCAGTGAAAGTCAATGCATCT & \multirow[t]{2}{*}{70} & \multirow[t]{2}{*}{ [17] } \\
\hline & R: CCCCGTCCGCAGAAGTAAC & & \\
\hline \multirow[t]{2}{*}{ F5 } & F: GCTATTAGTGGTCATGGCACTGTAG & \multirow[t]{2}{*}{80} & \multirow[t]{2}{*}{ [17] } \\
\hline & R: TTTGTTTTCGCTAGGCAGTCATTA & & \\
\hline \multirow[t]{2}{*}{ F6 } & F: CCAAAGTATTCCACTGCAAGCA & \multirow[t]{2}{*}{72} & \multirow[t]{2}{*}{ [17] } \\
\hline & R: GCCGTAACTCCACCGTTTGT & & \\
\hline \multirow[t]{2}{*}{ F18 } & F: TTGTGCTTCCTTGTCCAATAAAAC & \multirow[t]{2}{*}{82} & \multirow[t]{2}{*}[17]{} \\
\hline & R: CTCCСCCTTGATTAGCAAAACC & & \\
\hline \multirow[t]{2}{*}{ F41 } & F: CTGCTGATTGGACGGAAGGT & \multirow[t]{2}{*}{88} & \multirow[t]{2}{*}{ [17] } \\
\hline & R: CCAGTCTTCCATAGCCATTTAACAG & & \\
\hline \multirow[t]{2}{*}{ LT } & F: CCGGCAGAGGATGGTTACAG & \multirow[t]{2}{*}{73} & \multirow[t]{2}{*}{ [17] } \\
\hline & R: GAATCCAGGGTTCTTCTCTCCAA & & \\
\hline \multirow[t]{2}{*}{ Sta } & F: GCAAAATCCGTTTAACTAATCTCAAA & \multirow[t]{2}{*}{91} & \multirow[t]{2}{*}{ [18] } \\
\hline & R:ACAGAAATAAAAATTGCCAACATTAGC & & \\
\hline
\end{tabular}

2.4.2. Identification of Porcine Enteric Disease Complex (PEDC) pathogens.

Refrigerated ileum and colon tissue samples were also used to identify PEDC pathogens. DNA was extracted using a commercial kit (DanaPure Spin Kit. Genedan S.L., Spain).

Afterwards, conventional PCR was performed using the technique described by Suh and Song (2005) [19] with a modification. Suh and Song (2005) [19] described a multiplex PCR for the simultaneous diagnosis of L. intracellularis, B. hyodisenteriae, and Salmonella spp. However, in order to increase the sensitivity of the technique, three simple PCRs for the diagnosis of each of the bacteria were performed.

If a positive result was found for any of the three pathogens, a real-time PCR would then be performed according to the methodology described in the Additional file. The Primers used are described in Table 4.

Table 4 - Characteristics of oligonucleotide sequences used for PCR assays to detect Porcine Enteric Disease Complex (PEDC) pathogens.

\begin{tabular}{|c|c|c|c|c|}
\hline PCR and samples & Virulence factor & Oligonucleotide sequence $\left(5^{\prime}-3^{\prime}\right)$ & $\begin{array}{l}\text { Size of amplified product } \\
\text { (bp) }\end{array}$ & Reference \\
\hline \multirow[t]{6}{*}{$\begin{array}{l}\text { Conventional PCR, ileum and } \\
\text { colon }\end{array}$} & \multirow[t]{2}{*}{ L. intracellularis } & $\begin{array}{l}\text { F: } \\
\text { GCAGCACTTGCAAACAATAAACT }\end{array}$ & \multirow[t]{2}{*}{210} & \multirow[t]{2}{*}{ [19] } \\
\hline & & $\begin{array}{l}\text { R: } \\
\text { TTCTССТTTСTСАTGTCCСАTAA }\end{array}$ & & \\
\hline & \multirow{2}{*}{$\begin{array}{l}\text { B. } \\
\text { hyodisenteriae }\end{array}$} & F: GCTGGAGATGATGCTTCTGG & \multirow[t]{2}{*}{403} & \multirow[t]{2}{*}{ [19] } \\
\hline & & R: GTCCAAGAGCTTGGCTGTTC & & \\
\hline & \multirow[t]{2}{*}{ Salmonella spp. } & F: TTGGTGTTTATGGGGTCGTT & \multirow[t]{2}{*}{298} & \multirow[t]{2}{*}{ [19] } \\
\hline & & R: GGGCATACCATCCAGAGAAA & & \\
\hline \multirow[t]{2}{*}{ Real-time PCR, ileum and colon } & \multirow[t]{2}{*}{ L intracellularis } & F: GCGCGCGTAGGTGGTTATAT & \multirow[t]{2}{*}{98} & \multirow[t]{2}{*}{ [20] } \\
\hline & & R: GCCACCCTCTCCGATACTCA & & \\
\hline
\end{tabular}




\subsection{Statistics}

Data were included in an Excel database and analyzed by SPSS v. 2215.0 (SPSS Inc., USA). The frequencies were analyzed by squared-Chi $\left(\chi^{2}\right)$ with adjusted residues analysis and the quantity of DNA copies of the pathogens when real-time PCR was performed was analyzed by T-student. The correlations were calculated with Spearman's correlation test. A difference was considered significant when $p<0.05$.

\section{Results}

\subsection{E. coli isolation and virulence factor genes on fecal samples}

Five and 17 samples of diarrhea were collected from Vaccinated and Control groups, respectively. No sample (0\%) from the Vaccinated group was positive, while $16(94.1 \%)$ samples from Control were positive $(\mathrm{p}<0.0001)$.

Eleven out of 16 isolates expressed one virulence factor; three expressed two virulence factors; one expressed three virulence factors; and one expressed four virulence factors (these virulence factors are disposed in table 5). There were no significant differences in the frequency of the virulence factors between the two groups (Table 6).

Table 5 - E. coli isolates and virulence factors found in fecal, intestinal mucosa swab, and ileum and colon tissue samples. 
Fecal Control

samples

$\begin{array}{llllllllllllll}1 & 1 & 0 & 0 & 0 & 0 & 0 & 0 & 0 & 0 & 0 & 0 & 0 & 1\end{array}$ $\begin{array}{rrrrrrrrrrrrrr}2 & 1 & 0 & 0 & 0 & 0 & 0 & 0 & 0 & 0 & 0 & 0 & 0 & 1\end{array}$ $\begin{array}{rrrrrrrrrrrrrr}3 & 1 & 0 & 0 & 0 & 0 & 0 & 0 & 0 & 0 & 0 & 0 & 0 & 1\end{array}$ $\begin{array}{rrrrrrrrrrrrrr}4 & 1 & 0 & 0 & 0 & 0 & 0 & 0 & 0 & 0 & 0 & 0 & 0 & 1\end{array}$ $\begin{array}{rlllllllllllll}5 & 1 & 0 & 0 & 0 & 0 & 0 & 0 & 0 & 0 & 0 & 0 & 0 & 1\end{array}$ $\begin{array}{llllllllllllll}6 & 1 & 0 & 0 & 0 & 0 & 0 & 0 & 0 & 0 & 0 & 0 & 0 & 1\end{array}$ $\begin{array}{rrrrrrrrrrrrrr}7 & 1 & 0 & 0 & 0 & 0 & 0 & 0 & 0 & 0 & 0 & 0 & 0 & 1\end{array}$

$\begin{array}{llllllllllllll}8 & 0 & 0 & 0 & 0 & 0 & 0 & 0 & 0 & 1 & 1 & 0 & 0 & 2\end{array}$

$\begin{array}{llllllllllllll}9 & 0 & 0 & 0 & 0 & 1 & 0 & 1 & 1 & 1 & 0 & 0 & 0 & 4\end{array}$
$\begin{array}{rlllllllllllll}10 & 0 & 0 & 0 & 0 & 0 & 0 & 0 & 0 & 0 & 1 & 0 & 0 & 1\end{array}$ $\begin{array}{llllllllllllll}11 & 0 & 0 & 0 & 0 & 0 & 0 & 0 & 0 & 0 & 1 & 0 & 0 & 1\end{array}$ $\begin{array}{llllllllllllll}12 & 0 & 0 & 0 & 0 & 0 & 0 & 0 & 1 & 0 & 1 & 0 & 0 & 2\end{array}$ $\begin{array}{rlllllllllllll}13 & 0 & 0 & 0 & 0 & 0 & 0 & 0 & 1 & 0 & 0 & 0 & 0 & 1\end{array}$ $\begin{array}{llllllllllllll}14 & 0 & 0 & 0 & 0 & 0 & 0 & 0 & 1 & 1 & 1 & 0 & 0 & 3\end{array}$ $\begin{array}{llllllllllllll}15 & 0 & 0 & 0 & 0 & 0 & 0 & 0 & 1 & 0 & 1 & 0 & 0 & 2\end{array}$ $\begin{array}{rlllllllllllll}16 & 0 & 0 & 0 & 0 & 0 & 0 & 1 & 0 & 0 & 0 & 0 & 0 & 1\end{array}$

Intestinal Control mucosa swab samples

$\begin{array}{rrrrrrrrrrrrrr}1 & 1 & 0 & 0 & 0 & 0 & 0 & 0 & 0 & 0 & 0 & 0 & 0 & 1\end{array}$

$\begin{array}{rrrrrrrrrrrrrr}2 & 1 & 0 & 0 & 0 & 0 & 0 & 0 & 0 & 0 & 0 & 0 & 0 & 1\end{array}$

$\begin{array}{llllllllllllll}3 & 0 & 0 & 0 & 0 & 0 & 0 & 0 & 0 & 0 & 1 & 0 & 0 & 1\end{array}$

$\begin{array}{llllllllllllll}4 & 0 & 0 & 0 & 0 & 0 & 0 & 0 & 0 & 0 & 1 & 0 & 0 & 1\end{array}$

$\begin{array}{rrrrrrrrrrrrrr}5 & 0 & 0 & 0 & 0 & 0 & 0 & 1 & 0 & 0 & 0 & 0 & 0 & 1\end{array}$
colon

\begin{tabular}{|c|c|c|c|c|c|c|c|c|c|c|c|c|c|c|}
\hline \multirow[t]{5}{*}{ Vaccinated } & 1 & - & 0 & 0 & 0 & 0 & 0 & - & 1 & 0 & - & - & - & 1 \\
\hline & 2 & - & 0 & 0 & 0 & 0 & 0 & - & 1 & 0 & - & - & - & \\
\hline & 3 & - & 0 & 0 & 0 & 0 & 1 & - & 0 & 1 & - & - & - & 2 \\
\hline & 4 & - & 0 & 0 & 0 & 0 & 1 & - & 1 & 1 & - & - & - & 3 \\
\hline & 5 & - & 0 & 0 & 0 & 0 & 1 & - & 0 & 0 & - & - & - & 1 \\
\hline \multirow[t]{8}{*}{ Control } & 1 & - & 0 & 0 & 0 & 0 & 1 & - & 0 & 0 & - & - & - & 1 \\
\hline & 2 & - & 0 & 0 & 0 & 0 & 1 & - & 0 & 1 & - & - & - & 2 \\
\hline & 3 & - & 0 & 0 & 0 & 0 & 0 & - & 0 & 1 & - & - & - & 1 \\
\hline & 4 & - & 0 & 0 & 0 & 0 & 1 & - & 1 & 1 & - & - & - & 3 \\
\hline & 5 & - & 0 & 0 & 0 & 0 & 0 & - & 1 & 0 & - & - & - & 1 \\
\hline & 6 & - & 0 & 0 & 0 & 0 & 1 & - & 1 & 1 & - & - & - & 3 \\
\hline & 7 & - & 0 & 0 & 0 & 0 & 1 & - & 1 & 0 & - & - & - & 2 \\
\hline & 8 & - & 0 & 0 & 0 & 0 & 1 & - & 0 & 1 & - & - & - & 2 \\
\hline
\end{tabular}




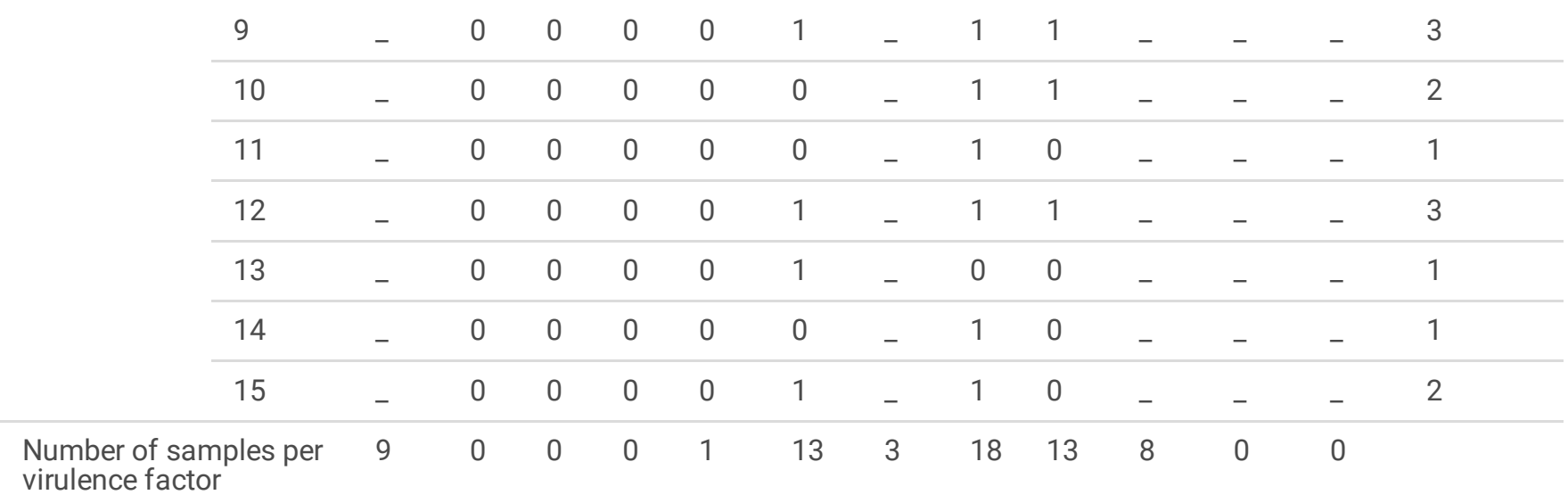

Table 6 - Total positive samples for E. coli and number of positive samples for each of the virulence factors of E. coli in fecal, intestinal mucosa swab, and ileum and colon tissue samples.

\begin{tabular}{|c|c|c|c|c|c|c|c|c|c|}
\hline \multirow{2}{*}{$\begin{array}{l}\text { Virulence } \\
\text { factors }\end{array}$} & \multicolumn{3}{|c|}{ Fecal samples } & \multicolumn{3}{|c|}{ Intestinal mucosa swab samples } & \multicolumn{3}{|c|}{ Ileum and colon tissue samples } \\
\hline & $\begin{array}{l}\text { Vaccinated } \\
\text { group }\end{array}$ & $\begin{array}{l}\text { Control } \\
\text { group }\end{array}$ & $\begin{array}{l}\text { P- } \\
\text { value }\end{array}$ & $\begin{array}{l}\text { Vaccinated } \\
\text { group }\end{array}$ & $\begin{array}{l}\text { Control } \\
\text { group }\end{array}$ & $\begin{array}{l}\mathrm{P} \text { - } \\
\text { value }\end{array}$ & $\begin{array}{l}\text { Vaccinated } \\
\text { group }\end{array}$ & $\begin{array}{l}\text { Control } \\
\text { group }\end{array}$ & $\begin{array}{l}\mathrm{P} \text { - } \\
\text { value }\end{array}$ \\
\hline eae & $0(0 \%)$ & $\begin{array}{l}7 \\
(41.17 \%)\end{array}$ & ns & $0(0 \%)$ & $2(40 \%)$ & ns & - & - & - \\
\hline Hly & $0(0 \%)$ & $\begin{array}{l}2 \\
(11.76 \%)\end{array}$ & ns & $0(0 \%)$ & $1(20 \%)$ & ns & - & - & - \\
\hline F18 & $0(0 \%)$ & $1(5.88 \%)$ & ns & $0(0 \%)$ & $0(0 \%)$ & ns & $0(0 \%)$ & $0(0 \%)$ & ns \\
\hline F4 & $0(0 \%)$ & $0(0 \%)$ & ns & $0(0 \%)$ & $0(0 \%)$ & ns & $0(0 \%)$ & $0(0 \%)$ & ns \\
\hline F41 & $0(0 \%)$ & $0(0 \%)$ & ns & $0(0 \%)$ & $0(0 \%)$ & ns & $3(15 \%)$ & $10(50 \%)$ & 0.018 \\
\hline F5 & $0(0 \%)$ & $0(0 \%)$ & ns & $0(0 \%)$ & $0(0 \%)$ & ns & $0(0 \%)$ & $0(0 \%)$ & ns \\
\hline F6 & $0(0 \%)$ & $0(0 \%)$ & ns & $0(0 \%)$ & $0(0 \%)$ & ns & $0(0 \%)$ & $0(0 \%)$ & ns \\
\hline LT & $0(0 \%)$ & $\begin{array}{l}5 \\
(29.41 \%)\end{array}$ & ns & $0(0 \%)$ & $0(0 \%)$ & ns & $3(15 \%)$ & $10(50 \%)$ & 0.018 \\
\hline Sta & $0(0 \%)$ & $\begin{array}{l}3 \\
(17.64 \%)\end{array}$ & ns & $0(0 \%)$ & $0(0 \%)$ & ns & $2(10 \%)$ & $8(40 \%)$ & 0.028 \\
\hline STb & $0(0 \%)$ & $\begin{array}{l}6 \\
(35.29 \%)\end{array}$ & ns & $0(0 \%)$ & $2(40 \%)$ & ns & - & - & - \\
\hline VT1 & $0(0 \%)$ & $0(0 \%)$ & ns & $0(0 \%)$ & $0(0 \%)$ & ns & - & - & - \\
\hline VT2 & $0(0 \%)$ & $0(0 \%)$ & ns & $0(0 \%)$ & $0(0 \%)$ & ns & _ & _ & - \\
\hline
\end{tabular}

Statistical analysis: Qui-square test.

ns= not significant; statistical significance $p<0.05$.

\subsection{E. coli isolation and virulence factor genes on intestinal mucosa swab}

Regarding intestinal mucosa swabs, all samples from Vaccinated group $(0 \%)$ were negative for $E$. coli, while all samples from Control group (100\%) were positive. All positive samples expressed only one virulence factor gene each (Table 5), however, due to the absence of positive samples in Vaccinated group, the difference between groups regarding the frequency of any virulence factor gene cannot be considered significant (Table 6).

3.3. Virulence factor genes identification in ileum and colon tissue samples

Page $9 / 15$ 
With respect to ileum and colon tissue samples, seven (35\%) Vaccinated group samples and 17 (85\%) Control group samples were positive for $E$. coli $(\mathrm{p}=0.001)$. On Vaccinated group, all seven samples were positive for only one virulence factor gene. Regarding Control group, 11 expressed one virulence factor gene, five samples expressed two virulence factors genes and one sample expressed three virulence factors genes. Furthermore, Control group had a higher frequency of F41 ( $p=0.018), L T(p=0.018)$, and Sta $(p=0.028)$ compared with Vaccinated (table 5 and 6).

\subsection{Identification of the Porcine Enteric Disease Complex (PEDC) pathogens}

No sample was positive for Salmonella spp. or B. hyodisenteriae.

By contrast, using conventional PCR we identified five and one positives for $L$. intracellularis in ileum and colon samples from Vaccinated group, respectively; and eight and four from Control group, also respectively.

When real-time PCR was used, the frequencies raised to eight and four in Vaccinated and 20 and 14 for Control group ( $p<0.001$ for ileum and $p=0.001$ for colon). Moreover, the bacteria was present in ileum and colon simultaneously in 14 animals $(70 \%)$ from Control and only in three $(15 \%)$ from Vaccinated group $(\mathrm{p}<0.0001)$.

The quantity of $L$. intracellularis DNA copies was significantly different in both groups in the ileum $(p<0.0001)$ and colon $(p<0.0001)$ samples (Table 7). There was a positive correlation between the quantity in ileum and colon $(r=0,850, p<0,001)$

Table 7 - Positive/negative samples by classic and real-time PCR (+/-) analysis and DNA copies quantity of L. intracellularis in ileum and colon as determined by real-time PCR.

\begin{tabular}{|c|c|c|c|c|c|c|}
\hline & \multicolumn{3}{|l|}{ Ileum } & \multicolumn{3}{|l|}{ Colon } \\
\hline & $\begin{array}{l}\text { Vaccinated } \\
\text { group }\end{array}$ & Control group & P-value & $\begin{array}{l}\text { Vaccinated } \\
\text { group }\end{array}$ & Control group & P-value \\
\hline L. intracellularis & $5 / 20(25 \%)$ & $8 / 20(40 \%)$ & ns & $1 / 20(5 \%)$ & $4 / 20(20 \%)$ & ns \\
\hline \multicolumn{7}{|l|}{ Conventional PCR } \\
\hline L. intracellularis & $8 / 20(40 \%)$ & $20 / 20(100 \%)$ & $p<0.001$ & $4 / 20(20 \%)$ & $14 / 20(70 \%)$ & $p=0.001$ \\
\hline \multicolumn{7}{|l|}{ Real time PCR } \\
\hline L. intracellularis & $70 \pm 43$ & $1,447,781 \pm 1,193,306$ & $p<0.0001$ & $12,4 \pm 6,1$ & $3,288.3 \pm 27,883.3$ & $p<0.0001$ \\
\hline
\end{tabular}

Statistical analysis: Qui-square test to analyze frequencies of positive/negative animals for $L$. intracellularis; T-student test to analyze the quantity of DNA copies of L. intracellularis.

ns $=$ not significant; statistical significance $p<0.05$

\section{Discussion}

Most studies focus on sow vaccination in order to generate antibodies that will be transferred to the piglet via colostrum and milk intake [21-23], which is also a common practice in commercial pig farms. However, this type of immunization cannot guarantee a long-lasting immunity to animals, since the amount of maternal antibodies circulating in the plasma of piglets decreases significantly after weaning [5].

This was the first study that evaluated the efficacy of a multivalent intramuscular vaccine against pathogenic $E$. coli applied directly to the suckling piglet under field conditions. Bianchi et al. (1996) [24] also tested intramuscular E. coli vaccine in piglets, but the vaccine had only one fimbrial antigen, tested under experimental conditions and did not generate immunological protection in animals. Melkebeek et al. (2007) [25] also evaluated the efficacy of a parenteral vaccine, but subcutaneously and it did not generate protection of piglets against infection either. 
Some studies have also evaluated the efficacy of oral vaccines for suckling piglets, to develop lasting immunity [26,27]. Although they proved effective, there are difficulties in putting oral vaccines into use, whether administered via drinking water - it is difficult to ensure that all animals have instilled enough antigens to be immunized - or directly into the mouth of the piglet - which requires training to prevent aspiration of fluid into the lungs. Furthermore, these studies evaluated only vaccines with one or two fimbrial antigens, which may not be sufficient to generate immunity against $E$. coli strains that do not specifically express these fimbriae $[27,28]$.

It is very important to ensure complete immunity to the animal. In the present study, the vaccine used had antigens F4, F5, F41, F18, F6, LT, STa, VT and Hly. These are common antigens expressed by pathogenic E. coli from farms, as has already been described in several studies [29-32] and by the present study, in which strains of $E$. coli were identified expressing the factors F18, F41, LT, Hly, STa and others that were not contemplated by the vaccine: eae and STb.

This was also the first study that looked for virulence factors of $E$. coli in three types of sample: stool, intestinal swab and intestine fragment - ileum and colon. This translates into very sound results, as the method minimizes the chance overlooking traces of the pathogenic form of this bacterium if present. We have found different results for samples collected at the same time (swab and fragment) regarding the presence or absence of different virulence factors.

Using these three types of samples, we have found that the vaccine applied directly to piglets reduced the amount of positive animals for pathogenic $E$. coli. This shows, for the first time, that this type of immunization can be used as a control tool for post-weaning colibacillosis, and that its effect is lasting until slaughter. This conclusion can be extracted from two facts: there were no animals in the vaccinated group in the farm that tested positive for $E$. coli in fecal samples and the positive samples collected from intestinal swab and intestinal fragment in the slaughterhouse were less than in the control group.

One point that could be raised as a weakness of our study is the smaller amount of diarrheal stool samples collected in the Vaccinated Group; however, this reinforces the hypothesis that the vaccine is effective, since feces were collected only from diarrheic animals, indicating a lower diarrhea rate in the vaccinated group.

Regarding the genes of virulence factors, only six of the 12 surveyed were found, following the order of prevalence: LT (18 of the 41 positive samples $-43.9 \%$ ), eae (9 of 21 positive samples $-42.8 \%$ ), STb (8 of 21 positive samples - 38.1\%), F41 (13 of 41 positive samples $-31.7 \%$ ) and STa (13 of 41 positive samples $-31.7 \%$ ), Hly (3 of 21 positive samples $-14.28 \%$ ) and F18 (1 of 41 positive samples - $2.43 \%)$.

Among these virulence factor genes, the only three genes that encode the expression of adhesin proteins are eae - encodes intimin, F18 and F41 [33,34]. Almost half of the isolates (48.8\%) did not express any gene responsible for the adhesion, but this does not mean that these bacteria are not able to bind to host cells, but that probably the genes responsible for the adhesion were not contemplated in the present study. Still, according to Liu et al. (2014) [29], there may be a gap in the virulence factors already described, because they also found isolates that did not express any known adhesins and could bind in the intestine and cause diarrhea in piglets.

The STa, STb and LT genes encode homonymous enterotoxins, described as the most present in diarrhea caused by $E$. coli in stages after weaning [35]. This confirms the results of the present study, as these were the only enterotoxins identified. However, the significant difference between groups occurred only in the ileum and colon tissue samples for the LT factor; this is probably due to the greater number of tissue samples when compared to the number of stool samples and mucosal swabs. Furthermore, the sensitivity of $\mathrm{PCR}$ in feces is lower due to the large number of inhibition factors [36].

Hemolysin, encoded by the Hly gene, gives $E$. coli the characteristic of causing hemolysis. In several studies in which the prevalence of pathogenic $E$. coli virulence factors was estimated, the search for hemolysin was not contemplated $[31,37,38]$. In the present study, about $15 \%$ of the isolates had this gene. This is not a high percentage, but this data shows that Hly virulence factor has some importance in colibacillosis of nursery and finishing animals.

In addition, all of the isolates that presented two or more virulence factors belonged to the control group. Virulence factors have a synergistic effect and, therefore, the greater the number of factors expressed by an isolate, the greater its pathogenicity [29]. This shows that vaccination in the piglet, in addition to reducing the prevalence of $E$. coli, also prevented colonization of the intestine by more pathogenic isolates. 
Regarding the pathogens of PEDC, only the bacterium L. intracellularis was identified. The high prevalence of co-infection of $E$. coli and L. intracellularis is significant. As $100 \%$ of Control group gut tissue samples were positive for L. intracellularis and $75 \%$ of these same samples were positive for $E$. coli, we can infer that $75 \%$ of these animals were concomitantly positive for both bacteria. To date, studies have identified co-infection of $E$. coli and $L$. intracellularis in a maximum of $31.6 \%$ of pigs [39-41]. It is likely that this great difference between studies is justified by the type of sample used, since all the studies mentioned used feces for the diagnosis of $L$.

intracellularis. As its excretion is intermittent [42], the sensitivity in tissue fragments is higher. This also leads us to conclude that the prevalence of co-infection of E. coli and L. intracellularis is higher than was estimated in previous studies.

In addition to this, the amount of DNA copies of L. intracellularis was up to 20,000 times higher in the Control group than in the Vaccinated group. This may evidence the existence of an association between $E$. coli and $L$. intracellularis, because animals from the vaccinated group that had a lower amount of pathogenic $E$. coli in the intestine had also a drastic reduction of $L$. intracellularis. E. coli breaks the homeostasis of the intestinal microbiota, favoring colonization and increased intensity of $L$. intracellularis infection $[1,43]$.

In this context, the results also reaffirm that vaccines against a specific enteric pathogen can reduce colonization and excretion of other enteric pathogens. Leite et al. (2018) [44] and Meschede (2014) [45], when vaccinating pigs against L. intracellularis, observed a reduction in the prevalence and excretion of Salmonella sp. Regarding the E. colivaccine, this is the first study that shows this ability, showing that this vaccine can also help in the control of swine proliferative enteropathy, serving as an alternative for the control of this infection.

\section{Conclusions}

The results indicate that the $E$. coli vaccine for piglets may be a strategy to control $E$. coli infection. That may be an alternative to the vaccination of sows to protect the piglet, which is effective for the first weeks of life but probably not for older pigs. Furthermore, $L$. intracellularis and E. coli, being components of the PEDC, have interactions between them. When the vaccine protects the animal against $E$. coli infection, reducing $E$. coli colonization, it also affects $L$. intracellularis, reducing the colonization of the last one in the intestine. Due to that, $E$. coli vaccines emerge as a probable strategy to help control L. intracellularis and, maybe, other enteric pathogens of pigs not evaluated in this study.

\section{Declarations}

\section{Ethics approval}

The committee of animal welfare at the University of Murcia examined and approved all experimental protocols. The animals were raised based on Spanish law that establishes basic standards for pig farms (Royal Decree 306/2020) and welfare (Law 32/2007). The study was carried out in accordance with the EU Directive 2010/63/EU for animal experiments.

\section{Consent for publication}

Not applicable

Availability of data and materials

All data generated or analysed during this study are included in this published article (and its supplementary information files).

Competing interests

The authors declare no competing interests.

Funding

This work was supported by “Dirección General de Investigación de la Consejería de Educación y Cultura” of Murcia (SUE-GAN 07/010010).

Authors' contributions 
M. G. Ramis-Vidal and A. Muñoz led and designed the study. M. G. Ramis-Vidal performed the statistical analysis of the results. L. M. Pascoal was the principal investigator of this study and collected the samples on the farm and on the slaughterhouse. L. M. Pascoal, F. J. Pallarés, J. J. Quereda and J. M. H. Medrano performed the PCRs assays (Real-time PCR, Real-time PCR-based "Plus/Minus" and classical PCR). L. M. Pascoal and S. R. Chagas reviewed and analyzed the data and wrote the manuscript. All authors reviewed and approved the final version of this manuscript for publication.

\section{Acknowledgements}

The authors thank the "Dirección General de Investigación de la Consejería de Educación y Cultura" of Murcia for the financial support and Vetia Animal Health for providing the vaccine used. The authors also thank the pig farm JYSAPS for allowing the researchers to perform the study there, and specially José María González, Joaquín Martínez, Ángel Gárrido, and Helena Sanjosé for data collection and for performing the necropsies. Furthermore, J.J. Quereda is supported by a "Ramón y Cajal" contract of the Spanish Ministry of Science, Innovation, and Universities (RYC-2018-024985-I)

\section{References}

1. Cano G. Porcine enteric complex. Suis. 2009;14-22.

2. Sun X, Jia Z. Microbiome modulates intestinal homeostasis against inflammatory diseases. Veterinary Immunology and Immunopathology. 2018;205.

3. Fairbrother JM, Nadeau É. Colibacillosis. Diseases of Swine. Wiley; 2019.

4. Fairbrother JM, Nadeau É, Gyles CL. Escherichia coli in postweaning diarrhea in pigs: an update on bacterial types, pathogenesis, and prevention strategies. Animal Health Research Reviews. 2005;6.

5. Matías J, Berzosa M, Pastor Y, Irache J, Gamazo C. Maternal Vaccination. Immunization of Sows during Pregnancy against ETEC Infections. Vaccines. 2017;5.

6. Landers TF, Cohen B, Wittum TE, Larson EL. A Review of Antibiotic Use in Food Animals: Perspective, Policy, and Potential. Public Health Reports. 2012;127.

7. Marquardt RR, Li S. Antimicrobial resistance in livestock: advances and alternatives to antibiotics. Animal Frontiers. 2018;8.

8. Parma AE, Viñas MR, Sanz ME. Improvement of the polymerase chain reaction to detect Escherichia coli Shiga-like toxin II gene from clinical isolates. Journal of Microbiological Methods. 1996;26.

9. Sanz ME, Viñas MR, Parma AE. Prevalence of bovine verotoxin-producing Escherichia coli in Argentina. European Journal of Epidemiology. 1998;14.

10. Blanco M, Blanco JE, Mora A, Rey J, Alonso JM, Hermoso M, et al. Serotypes, Virulence Genes, and Intimin Types of Shiga Toxin (Verotoxin)-Producing Escherichia coli Isolates from Healthy Sheep in Spain. Journal of Clinical Microbiology. 2003;41.

11. Schmidt H, Beutin L, Karch H. Molecular analysis of the plasmid-encoded hemolysin of Escherichia coli 0157:H7 strain EDL 933. Infection and immunity. 1995;63.

12. Blanco M, Blanco JE, Gonzalez EA, Mora A, Jansen W, Gomes TA, et al. Genes coding for enterotoxins and verotoxins in porcine Escherichia coli strains belonging to different O:K:H serotypes: relationship with toxic phenotypes. Journal of clinical microbiology. 1997;35.

13. Penteado AS, Ugrinovich LA, Blanco J, Blanco M, Blanco JE, Mora A, et al. Serobiotypes and virulence genes of Escherichia coli strains isolated from diarrheic and healthy rabbits in Brazil. Veterinary Microbiology. 2002;89.

14. Blanco M, Blanco JE, Mora A, Dahbi G, Alonso MP, Gonzalez EA, et al. Serotypes, Virulence Genes, and Intimin Types of Shiga Toxin (Verotoxin)-Producing Escherichia coli Isolates from Cattle in Spain and Identification of a New Intimin Variant Gene (eae-). Journal of Clinical Microbiology. 2004;42.

15. Franklin MA, Francis DH, Baker D, Mathew AG. A PCR-Based Method of Detection and Differentiation of K88 ${ }^{+}$Adhesive Escherichia Coli. Journal of Veterinary Diagnostic Investigation. 1996;8.

16. Blanco M, Lazo L, Blanco JE, Dahbi G, Mora A, López C, et al. Serotypes, virulence genes, and PFGE patterns of enteropathogenic Escherichia coli isolated from Cuban pigs with diarrhea. International microbiology [Internet]. 2006 [cited 2021 May 13];9:53-60. Available from: https://pubmed.ncbi.nlm.nih.gov/16636990/ 
17. West DM, Sprigings KA, Cassar C, Wakeley PR, Sawyer J, Davies RH. Rapid detection of Escherichia coli virulence factor genes using multiplex real-time TaqMan® PCR assays. Veterinary Microbiology. 2007;122.

18. Frydendahl K, Imberechts H, Lehmann S. Automated 5 ' nuclease assay for detection of virulence factors in porcine Escherichia coli. Molecular and Cellular Probes. 2001;15.

19. Suh DK, Song JC. Simultaneous detection of Lawsonia intracellularis, Brachyspira hyodysenteriae and Salmonella spp. in swine intestinal specimens by multiplex polymerase chain reaction. Journal of veterinary science. 2005;6:231-7.

20. Lindecrona RH, Jensen TK, Andersen PH, Moller K. Application of a 5' Nuclease Assay for Detection of Lawsonia intracellularis in Fecal Samples from Pigs. Journal of Clinical Microbiology. 2002;40.

21. Hur J, Lee JH. Comparative evaluation of a vaccine candidate expressing enterotoxigenic Escherichia coli (ETEC) adhesins for colibacillosis with a commercial vaccine using a pig model. Vaccine. 2012;30.

22. Hur J, Lee JH. Development of a novel live vaccine delivering enterotoxigenic Escherichia coli fimbrial antigens to prevent postweaning diarrhea in piglets. Veterinary Immunology and Immunopathology. 2012;146.

23. Zhang H, Xu Y, Zhang Z, You J, Yang Y, Li X. Protective immunity of a Multivalent Vaccine Candidate against piglet diarrhea caused by enterotoxigenic Escherichia coli (ETEC) in a pig model. Vaccine. 2018;36.

24. Bianchi ATJ, Scholten J-W, van Zijderveld AM, van Zijderveld FG, Bokhout BA. Parenteral vaccination of mice and piglets with F4+Escherichia coli suppresses the enteric anti-F4 response upon oral infection. Vaccine. 1996;14.

25. Melkebeek V, Verdonck F, Goddeeris BM, Cox E. Comparison of immune responses in parenteral FaeG DNA primed pigs boosted orally with F4 protein or reimmunized with the DNA vaccine. Veterinary Immunology and Immunopathology. $2007 ; 116$.

26. Fairbrother JM, Nadeau É, Bélanger L, Tremblay C-L, Tremblay D, Brunelle M, et al. Immunogenicity and protective efficacy of a single-dose live non-pathogenic Escherichia coli oral vaccine against F4-positive enterotoxigenic Escherichia coli challenge in pigs. Vaccine. 2017;35.

27. Nadeau É, Fairbrother JM, Zentek J, Bélanger L, Tremblay D, Tremblay C-L, et al. Efficacy of a single oral dose of a live bivalent E. coli vaccine against post-weaning diarrhea due to F4 and F18-positive enterotoxigenic E. coli. The Veterinary Journal. $2017 ; 226$.

28. Bertschinger HU, Nief V, Tschäpe H. Active oral immunization of suckling piglets to prevent colonization after weaning by enterotoxigenic Escherichia coli with fimbriae F18. Veterinary Microbiology. 2000;71.

29. Liu W, Yuan C, Meng X, Du Y, Gao R, Tang J, et al. Frequency of virulence factors in Escherichia coli isolated from suckling pigs with diarrhoea in China. The Veterinary Journal. 2014;199.

30. Vidotto MC, Florian ECT, Ono MA. Prevalence of the paa gene (porcine attaching and effacing associated) in porcine enteropathogenic Escherichia coli (PEPEC) associated with postweaning diarrhea in south Brazil. Brazilian Journal of Microbiology. 2013;44.

31. Luppi A, Gibellini M, Gin T, Vangroenweghe F, Vandenbroucke V, Bauerfeind R, et al. Prevalence of virulence factors in enterotoxigenic Escherichia coli isolated from pigs with post-weaning diarrhoea in Europe. Porcine Health Management. $2016 ; 2$.

32. Bessone FA, Bessone G, Marini S, Conde MB, Alustiza FE, Zielinski G. Presence and characterization of Escherichia coli virulence genes isolated from diseased pigs in the central region of Argentina. Veterinary World. 2017;10.

33. Mundy R, Schüller S, Girard F, Fairbrother JM, Phillips AD, Frankel G. Functional studies of intimin in vivo and ex vivo: implications for host specificity and tissue tropism. Microbiology. 2007;153.

34. Smeds A, Hemmann K, Jakava-Viljanen M, Pelkonen S, Imberechts H, Palva A. Characterization of the Adhesin of Escherichia coli F18 Fimbriae. Infection and Immunity. 2001;69.

35. Luppi A. Swine enteric colibacillosis: diagnosis, therapy and antimicrobial resistance. Porcine Health Management. $2017 ; 3$.

36. Schrader C, Schielke A, Ellerbroek L, Johne R. PCR inhibitors - occurrence, properties and removal. Journal of Applied Microbiology. $2012 ; 113$.

37. Ikwap K, Larsson J, Jacobson M, Owiny DO, Nasinyama GW, Nabukenya I, et al. Prevalence of adhesin and toxin genes in E. coli strains isolated from diarrheic and non-diarrheic pigs from smallholder herds in northern and eastern Uganda. BMC Microbiology. 2016;16.

38. Zhang W, Zhao M, Ruesch L, Omot A, Francis D. Prevalence of virulence genes in Escherichia coli strains recently isolated from young pigs with diarrhea in the US. Veterinary Microbiology. 2007;123. 
39. Wendt M, Johann RS, Verspohl J. Epidemiological investigations on Lawsonia intracellularis infection in pig herds. Tierarztl Prax. 2006;34:230-9.

40. Weber N, Nielsen JP, Jakobsen AS, Pedersen L-L, Hansen CF, Pedersen KS. Occurrence of diarrhoea and intestinal pathogens in non-medicated nursery pigs. Acta Veterinaria Scandinavica. 2015;57.

41. Ståhl M, Kokotovic B, Hjulsager CK, Breum S $\emptyset$, Angen $\emptyset$. The use of quantitative PCR for identification and quantification of Brachyspira pilosicoli, Lawsonia intracellularis and Escherichia coli fimbrial types F4 and F18 in pig feces. Veterinary Microbiology. 2011;151.

42. Ramis G, Otero LC, Pallarés FJM, Rafael J, Astorga Marquez RJA, Muñoz AM, et al. Patologías digestivas porcinas en imágenes. 1st ed. Zaragoza: Servet; 2011.

43. Mølbak L, Johnsen K, Boye M, Jensen TK, Johansen M, Møller K, et al. The microbiota of pigs influenced by diet texture and severity of Lawsonia intracellularis infection. Veterinary Microbiology. 2008;128.

44. Leite FLL, Singer RS, Ward T, Gebhart CJ, Isaacson RE. Vaccination Against Lawsonia intracellularis Decreases Shedding of Salmonella enterica serovar Typhimurium in Co-Infected Pigs and Alters the Gut Microbiome. Scientific Reports. 2018;8.

45. Meschede J. Reduzierung der Salmonellenprävalenz in Lawsonia intracellularis- infizierten Schweinebeständen mittels Enterisol ${ }^{\circledR}$ Ileitis-Impfung. Der Praktische Tiezarzt. 2014;95:749-56.

\section{Supplementary Files}

This is a list of supplementary files associated with this preprint. Click to download.

- additionalfile1.docx 